\title{
EXAMINING JUDICIAL DECISIONS ON THE TERMS CASE STATED AND REFERENCE ON CONSTITUTIONAL QUESTIONS IN A COMMON LAW JURISDICTION
}

\author{
T.A. Yusuf (Esq), E.L. Effiong (Esq) G.R.C. Ibekwe \\ Deputy Director (Academic), Nigerian Law School. Email: taofikyusuflaw @yahoo.co.uk. \\ Tell; $08063304748,08055840441$. \\ Deputy Director (Academic), Nigerian Law School. \\ Senior Lecturer, Nigerian Law School.
}

Cite this article:

Yusuf T.A., Effiong E.L., Ibekwe G.R.C. (2021),

Examining Judicial Decisions on the Terms Case Stated and Reference on Constitutional Questions in A Common Law Jurisdiction. African Journal of Law, Political Research and Administration 4(2), 1-20. DOI: 10.52589/AJLPRACLLCKJ31.

\section{Manuscript History}

Received: 10 June 2021

Accepted: 3 July 2021

Published: 17 July 2021

Copyright () 2020 The Author(s). This is an Open Access article distributed under the terms of Creative Commons AttributionNonCommercial-NoDerivatives 4.0 International (CC BY-NC-ND 4.0), which permits anyone to share, use, reproduce and redistribute in any medium, provided the original author and source are credited.
ABSTRACT: The library is to a lawyer what a laboratory is to a scientist. While conducting research in the library, a lawyer sometimes may come across legal terms, the meaning and use of which he must be certain about so as not to convey another meaning other than the one, he has in mind to his audience or reader. Legal terms and expressions sometimes could be synonymous and to the unwary legal researcher to be the same. An example of this are the terms 'Case stated' and 'Reference on constitutional questions. The objective of this paper is to highlight the similarities and differences if any between the two legal terms and its data is derived from specific decided cases from the common law jurisdiction of Nigeria which would be used in pursuit of its stated objective.

KEYWORDS: Judicial Decisions, Terms Case Stated, Constitutional Questions, Common Law Jurisdiction 


\section{INTRODUCTION}

The register of the legal profession is no doubt very wide and varied, many of which originate in the Latin language. The terms 'case stated' and 'reference on Constitutional questions' are two such of the wide variety of terms or expressions in law that may seem to the pedestrian legal linguist to be of the same colour but of different hues or shades.

Even though a court is presumed to have the law in its bosom ${ }^{1}$, it sometimes finds it necessary or is compelled to seek the opinion of courts higher than it in the hierarchy of courts on legal issues that arise from proceedings before it which may be statutory or constitutional. Hence, the need to state a case or refer a Constitutional question to a higher court. This forms the plank of this paper which aims to examine the incidence of the two terms or expressions, ancillary issues and whether they are synonyms or antonyms. The research area of this paper would be limited to the common law jurisdiction of Nigeria.

\section{CASE STATED}

For a court to state a case to a higher court, there must be an enabling provision of a law to that effect. Hence, a court does not have the inherent jurisdiction to state a case without an enabling provision in a statute. ${ }^{2}$ To that extent, it may be opined that stating a case is not restricted to inferior courts of record. Even superior courts of record may state a case right up to the Supreme Court $^{3}$. We crave in fortification of this proposition the provisions of Order 5 of the Court of Appeal Rules, 2016 which provides for references as to the Constitution and reserved points of law. Rule 1 of the Order provides inter-alia that "when a lower court refers any question as to the interpretation of the Constitution under the relevant provisions of the Constitution, or reserves any question of law for the consideration of the court in accordance with any written law, the lower court referring or reserving the question of law, as the case may be, shall state a case in Form 1 or 2 in the First Schedule to these Rules, whichever may be appropriate, and the registrar of the lower court shall forward ten copies directly to the Registrar".

It is our view that 'any written law' in the context of Order 5 of the Court of Appeal Rules should be a law of the National Assembly which confers on the Federal High Court, the National Industrial Court, the Court of Appeal or any other federal court the power to state a case.

A similar provision to Order 5 of the Court of Appeal Rules is Order 4 of the Supreme Court Rules, 2014 (as amended). Rule 1 of the said Order provides that "The parties to a proceedings

\footnotetext{
${ }^{1}$ See Finnih v Imade (1992) NSCC (Vol.23) (pt.1) 56.

${ }^{2}$ For the meaning of inherent jurisdiction see Ally v State [2010] All FWLR (pt.546) 444 at 454-455. The Court of Appeal Calabar Division posited thus: "Inherent jurisdiction or inherent power of court is that which is not expressly spelt out by the Constitution or in any statute or rule but which can of necessity be invoked by any court of record to supplement its express jurisdiction or power conferred on courts of record by the Constitution or any rule of court. It also means the power which attaches to and inheres in a court by the very fact, and no other than, that it is a court, such power need not be legislated. Inherent derives from the Latin maxim, inhaerer inhaesum"

${ }^{3}$ In fortification of this point see Order 5 of the Court of Appeal Rules, 2016 and Order 4 and 5 of the Supreme Court Rules 2014 (as amended) which provides for the starting of a case and references as to the Constitution and reserved points of law from lower courts in the hierarchy of courts to those courts.
} 
commenced by statement of claim, originating summons or originating motion may at any stage concur in stating the question of law arising in the proceeding in the form of a case stated for the opinion of the Court."

The Constitution of the Federal Republic of Nigeria 1999 (as amended) does not expressly prohibit a law being enacted allowing cases to be stated even to the Supreme Court but such powers cannot be hinged on the provisions of the Constitution because the powers of reference thereat are limited to the interpretation and application of the provisions of the Constitution.

We posit that a court cannot rely on a procedural law to state a case in the absence of a substantive law. A procedural law on case stated is merely as to the form the case stated should take and other ancillary issues in that regard and cannot enable the same. An example of such procedural provisions are Section 243A CPA for the procedure in criminal matters on reference of constitutional questions, Order 5 of the Court of Appeal Rules, 2016 and Order 4 and 5 of the Supreme Court Rules which provides for Case Stated and References as to the Constitution and reserved points of law.

However, where the enabling legislative provision has been repealed then the case stated would not be entertained. In Rex $v$ Terkje \& Anor ${ }^{4}$ it was held per Verity, C.J. thus:

From and after the passing of the Criminal Procedure Ordinance, 1945 (Cap. 43 in the 1948 Revision of the Laws of Nigeria) which was repealed, without re-enacting section 191 of the former Criminal Procedure Ordinance, there is no power from a Judge of the Supreme Court sitting at first instance in a criminal proceeding to reserve a question of law for the opinion of the West African Court of Appeal.

Therefore, we are of the opinion that at the present time a Judge of the Supreme Court has no power to reserve and this Court no power to hear and determine any such questions of law, and that the learned Judge should himself determine any such questions in the proceedings before him, leaving it to the accused persons if put on their trial and convicted to appeal to this court if they so desire, for the present case stated cannot be entertained.

Other examples of such enabling legislation presently under discourse are Section 76 of the Magistrate's Court Law of Lagos State, 2009 which provides that 'where in any criminal case in which no public officer is a party and the Attorney-General is of the opinion that any decision of a Magistrate is erroneous in law, he may, at any time within six (6) months from the date of the decision, require the Magistrate to state a case on it for the opinion of the High Court.' The law also provides that in addition to and without prejudice to the right of appeal conferred by the law or any other law, a Magistrate may reserve for consideration by the High Court on a

\footnotetext{
${ }^{4} 12$ W.A.C.A. 478 at 478 . This is a case stated by Wells Palmer, J., in the course of criminal proceedings before him in the Supreme Court in which two persons were charged with child stealing, abduction and entering a dwelling house with intent to commit a felony. The learned Judge discharged the accused on the first count and then, as it would appear, without proceeding with the trial on the second and third counts, stated a case as to whether certain earlier proceedings in a Native Court were a nullity and whether the first accused can be tried in the Supreme Court on counts 2 and 3 having regard to such proceedings.
} 
case to be stated by him any question of law which may arise in any cause or matter before him and may give judgment or decision subject to the opinion of the High Court. ${ }^{5}$ In the same vein, the law by section 77 enthuses that a case stated by a Magistrate shall set out the - charges, summons, information or complaint; facts found by the Magistrate to be admitted or proved; submission of law made by or on behalf of the complainant during the trial or inquiry; submission of law made by or on behalf of the accused during the trial or inquiry; the finding of, and in case of conviction, the sentence imposed by the Magistrate; and question of law which the Attorney-General require to be submitted for the opinion of the High Court.

Where the enabling law provides for the same, the higher (appeal) court could, on application, order the lower court to state a case to it after the lower court had previously refused the same application by the applicant. ${ }^{6}$

A case stated is not restricted to criminal matters as illustrated by the provisions of Section 106(1) of the Lagos State Land Registration 2014, which provides that "If any question arises as regards the performance of any duty or the exercise of any function conferred on the Registrar by this Law, he may state a case for the opinion of the High Court."

A case should not be stated where there is no point of law involved. In Rex $v$ Robinson, ${ }^{7}$ It was held by the court per Webber, J; that: 'I am of the opinion that this appeal fails in that there is no point of law involved and that the Magistrate should have refused to state a case.'

In Native Authority of Akpabuyo v. Efion Enan \& 21 Ors,${ }^{8}$ the court posited that on a stated case, the Appeal Court may entertain a point of law not stated by the court below provided it is of a nature the effect of which no evidence could alter.

\footnotetext{
${ }^{5}$ See s. 78 of the Magistrate Court Law of Lagos State, 2009. See also $R$ V Eze (1950) 19 N.L.R 110. Herein, a person was charged under section 51(1) (c) before the Magistrate, Grade 1 at Enugu. Crown Counsel, prosecuting, submitted that this was an indictable offence, and, under section 304 of the Criminal Procedure Ordinance he informed the Magistrate that he did not consent to a summary trial; he requested the Magistrate to hold a preliminary inquiry. The Magistrate held that the offence charged was not indictable, but stated a case on this point at the request of Crown Counsel. The point of law to be considered depended on the construction of the definition of "indictable offence" contained in section 2 of the Criminal Procedure Ordinance; it is as follows: "indictable offence" means any offence - (a) which on conviction may be punished by a term of imprisonment exceeding two years, or (b) which on conviction may be punished by imposition of a fine exceeding two hundred pounds, or (c) which is not declared by the written law creating the offence to be punishable on summary conviction.

It was held that the expression "indictable offence" as defined in section 2 of the Criminal Procedure Ordinance (Cap. 43) does not include any offence triable summarily by a Magistrate under section 20 (1) (a) of the Magistrates' Court Ordinance (Cap. 122) whether or not the law creating the offence declares it punishable on summary conviction. The word "or" immediately preceding the letter "(c)" in the definition of "indictable offence" must be construed to mean "and".

${ }^{6}$ See Rex $v$ Doyle Richard Henshaw 12 N.L.R 26.

74 N.L.R. 91. In this case, the Master of the s.s. Gaboon was charged before the Station Magistrate at Port Harcourt with having brought the vessel into Port Harcourt without a pilot, contrary to rule 16 of Regulation No. 3 of 1922. The offence was admitted but it was argued that special circumstances justified the breach of the regulations. On conviction the Master was fined $£ 5$, and at his request a case was started by the Station Magistrate for the opinion of the Divisional Court.

87 N.L.R 92 at 93-95. This was a stated case in which one of the grounds for appeal was that the Commissioner of the Supreme Court who heard the case had in the course of it given a decision on a point of law which was at the time pending before the Judge in the Divisional Court. The appellants raised another point, which point had not been submitted to the Divisional Court in the case as stated by the Court below. It had been raised as a general plea before the Commissioner, but had not been argued, nor decided, nor made a ground for appeal.
} 
Likewise, the Appeal Court would not interfere with the judgment of the Court below where there was evidence upon which the Court below could have arrived at the conclusions it did. ${ }^{9}$

Callow J. in The King $v$ The Magistrate of the Court of the Colony Magisterial District in Re David Bello, ${ }^{10}$ is of the opinion that 'A case stated is more usually for determining the law applicable consequent upon certain facts found, and not to remedy an act in excess of jurisdiction; and whatever the procedure, it does not affect the right of the Attorney-General to demand a writ of certiorari.'

The case of Comptroller of Customs v. African Traders Co. Ltd., ${ }^{11}$ in our opinion is a good precedent as to the form a case stated should take which may be adopted by a judge (without prejudice to statutory forms earlier referred to) in stating a case to a higher court and same is reproduced hereunder:

The case stated by Webber, J., is as follows:-

The Defendant Company was charged before me on information with an offence under Section 49 of the Customs Ordinance, 1916which reads as follows:- "No prohibited imports shall be imported. Penalty: One hundred pounds."

The facts admitted are:- A large consignment of spirits, namely, Gin and Whiskey approximating in value $£ 12,000$ arrived in Nigeria for the African Traders Co., Ltd., whose principals in England are the agents of a Dutch firm by whom the spirits are supplied. The Dutch firm carries on business in Holland and the spirits are the product of Holland.

Of this consignment spirits ( 2 kinds of Gin and one of Whiskey) to the value of $£ 560$ were landed in Calabar and are in the King's Warehouse at Calabar at present. The invoices exhibits "A1" and "A2" contained the numbers of cases of Whiskey and Gin imported, their value, and their country of origin, namely, Holland.

On the cases in which the bottles containing the spirits are packed are the words stenciled "Produce of Holland." Each bottle is labelled and a specimen bottle of each of the three kinds is exhibited ("B1," "B2" and "B3").

\footnotetext{
${ }^{9}$ See Rex v Doyle Richard Henshaw, supra at 28. The appellant was found guilty of 'obstruction' under section 356(2) of the Criminal Code but not of 'assault'. The appellant in the course of a public disturbance advised the parties making the disturbance to disregard the orders of the police. As a result the crowd pushed the sergeant and his cap fell off.

1018 N.L.R 98 at 100. David Bello was convicted in the Magistrate's Court of the Colony Magisterial District on two charges of cheating contra. Section 421 of the Criminal Code and sentenced to six months imprisonment with hard labour on each count. The next day, the Magistrate wishing to exercise leniency amended the sentences to one sentence of a fine of three pounds or one month's imprisonment in default. The amendment was made in the absence of David Bello. The Crown took these proceedings by way of a writ of certiorari to remove the proceedings into the Supreme Court in order that the purported amendment of the sentence might be quashed on the ground that the Magistrate had no jurisdiction to amend the sentence.

11 N.L.R 85-86.
} 
Short evidence was taken and the Notes thereof are appended to the stated case.

For the Prosecution Regulation No. 13, 1916, Section 40 (2) and (3), and Section 50(a) and (b) of Customs Ordinance, 1916, were quoted as bringing the importation of the aforesaid goods under the category of prohibited imports.

For the Defence it was argued that:-

(1) The Regulations No. 13 of 1916 were ultra vires.

(2) Section 40 of the Regulations

(a) declaring such goods prohibited was ultra vires.

(b) does not apply to spirits.

(c) if it does apply, was complied with by the words "Produce of Holland" being put on the cases containing the spirits and on the Invoices submitted to the Collector of Customs.

(3) The goods imported were not prohibited under any law or Ordinances in Nigeria.

The question reserved by me for the consideration of the Full Court is as follows:- Has the Defendant Company imported prohibited imports?

If they have, the Defendant Company is guilty of an offence under Section 49, Customs Ordinance, 1916. If they have not, the Company is not guilty and the Defendant Company should be discharged.

Dated at Calabar the $10^{\text {th }}$ day of March, 1919.

(Sgd.) A. WEBBER,

Judge.

There are a plethora of other decided authorities in which cases have been stated (as distinct from an appeal) on questions of law to higher courts for the decision of the higher court. For instance, in Salametu Oyene $v$ Salihu Abogu ${ }^{12}$, the court held as follows:

Having regard to the facts as stated and all the circumstances, the question on which we are to give our opinion comes to this: "Is a Magistrate Grade 1 empowered by virtue of section 21 of the Land

\footnotetext{
${ }^{12}$ (1958) NNLR 103 at 104, 107 and 108, per Hurley, S.P.J in a written judgment which was read by McCarthy, Ag. J. In this case stated under section 110 of the Magistrates' Courts (Northern Region) Law, 1955, the Magistrate Grade 1, Ilorin asks for the opinion of this court on the following question:- Is a magistrate empowered by virtue of section 21 of the Land and Native Rights Ordinance as amended or by any other enactment to entertain a suit for a declaration of title in respect of land held under rights of occupancy.
} 
and Native Rights Ordinance as amended or by any other enactment to entertain a suit for a declaration of title of ownership of land under $£ 200$ in value held under a customary right of occupancy where the parties to the suit are persons subject to the jurisdiction of a native court and there is no native court of competent jurisdiction in the area where the land is situated...For the foregoing reasons we are of the opinion that the magistrate is not empowered to entertain this suit between persons subject to the jurisdiction of a native court for a declaration of title of ownership of land held under a customary right of occupancy in an area where there is no native court of competent jurisdiction, and that the answer to the question raised on the case stated is No... Since a right of occupancy is a title, such proceedings will necessarily be proceedings where title is in question.

In C.O.P V Momo Garko ${ }^{13}$, the learned magistrate put the following questions for the consideration of the court: (1) Does the fact that accused carried unauthorized passengers for reward constitute using the vehicle as a stage carriage? (2) If so, does that deprive the vehicle of the exemption from insurance conferred by s.5(a) of the Motor Vehicles (Third Party Insurance) Ordinance, or does the High Court hold the view that, the journey being an authorized one and the vehicle not having deviated from the proper course, the vehicle was still 'being used for the purposes of the Government owing it'?"

The court held in answer to the above question that:

The definition of 'stage carriage' in the Road Traffic Ordinance implies some element of regularity in the use of the vehicle as a stage carriage; and that whether a vehicle comes within the definition at any particular time is a question of fact which must depend upon the circumstances of each particular case. In the present case the vehicle was not being used as a stage carriage.

${ }^{13}$ (1958) NNLR 70 at 71, The accused pleaded guilty on the first charge to negligent driving, contrary to section 18(1) of the Road Traffic Ordinance; and on the second charge to carrying passengers and loads for reward without having a stage carriage licence, contrary to Regulation $67(\mathrm{~g})$ of the Road Traffic Regulations. He pleaded not guilty to a third charge of using a motor vehicle without a policy of insurance in respect of third party risks, contrary to section 3(1) of the Motor Vehicles (Third Party Insurance) Ordinance.

The accused was the driver of a kitcar belonging to the Ministry of Health. He was on an authorized journey from Kaduna to Wukari carrying departmental loads; and he did not deviate from his authorized route. At Lafia he picked up two passengers who paid 2s each to be taken to Makurdi and five bags of guinea corn for the same journey for which he was paid $1 s$ a bag. He was expressly forbidden by the Department to carry unauthorized loads or passengers. On the way to Makurdi he lost control of his vehicle, which mounted a heap of laterite and overturned. 
In the consolidated case stated for opinion of the High Court in Charge No. C.1375/76: Police V. Joshua Awopeju and Charge No. C/1372/76: Police V. Sulemon Okeshola ${ }^{14}$ Dosunmu J. held "All the questions asked can be summarized by saying whether either of all defendants is a competent witness against the other in the circumstance. The answer to the question is that it is not improper for the Police to charge the defendants separately, and that they be tried separately. Each of the defendants is a competent witness even where his own trial is being awaited."

In C.O.P V Idowu Awolana \& 3 Ors $^{15}$, the court held that there was no good cause for a Case Stated as there was sufficient material before the Magistrate's Court upon which to reach a just conclusion. Precisely, Adefarasin, C.J, Lagos State (as he then was) posited:

The learned Magistrate therefore had sufficient evidence before him upon which to determine the ownership of the property subject matter of the charge before him and whether it had been stolen from the $1^{\text {st }}$ prosecution witness. It is upon a decision on that issue that the question of restitution would arise.

In the Surveyor-General v. C.B. Thompson John, ${ }^{16}$ the judgment of the Divisional Court (Webber, J.) delivered on $16^{\text {th }}$ January, 1933, was as follows:-

This is a special case stated by Magistrate, Ebute Metta, relating to a claim for a penalty under section 8 of the Survey Ordinance which reads as follows:- "No person other than a surveyor shall make for fee or reward a survey of any land for the purpose of defining boundaries." It was found proved at the hearing: (a) That the defendant was not a licensed surveyor, and (b) That he received $£ 3$ as a fee to make a survey of land. It was admitted that although a fee was received no survey was, in fact, made by the defendant.

It was submitted by Crown Counsel that the fact that a fee was received by the defendant, an unlicensed surveyor, for the purpose

${ }^{14}$ (1977) 6 CCHCJ 1139 at 1144. By case stated under Secs. 66-69 of the Magistrate's Court Law, the Senior Magistrate, Mr. M.A. Kotun sought the opinion of the High Court on some questions. The background to these questions is this: On or about the $19^{\text {th }}$ August, 1976 two defendants, namely Joshua Awopeju and Sulemon Okeshola were involved in a motor collision on the Eko Bridge at about 5.55a.m. The Police decided to charge the two of them to Court separately under charge No. C/1375/76 and 1372/76 respectively for the offence of negligent driving of their respective cars by hitting the car of the other. At the trial of Joseph Awopeju, the Prosecution called as a witness Sulemon Okeshola against him. It is this procedure that the learned Senior Magistrate considered improper and that it would amount to attempting to traverse justice.

15 (1977) 6 CCHCJ 1145. The accused persons were charged with the offences of conspiracy to steal and stealing 960 cartons of Becks Beer and were arraigned before the Magistrate's court. It turned out that the Police had, on information received, visited the premises of the accused persons, seen the beer in question and permitted some of the accused and other persons to retain possession of the beer until such time as the beer might be required in court. The Learned Magistrate, by way of Case Stated, referred the questions whether the trial was a nullity having regard to irregularities concerning the search and return of some of the beer and whether in view of the adverse claims of a prosecution witness and the $3^{\text {rd }}$ accused person in the charge he was competent to order restitution. The learned Magistrate also wanted to know whether by releasing some of the goods found there had been contempt of court. The prosecution and the defence had closed their respective cases and addressed the court before the decision was taken to state a case.

1611 N.L.R 115. 
of making a survey the penalty was recoverable under the section, although a survey was not in fact made. I am unable to agree with this contention: The ingredients necessary to make the penalty under the section recoverable are- (a) the making of the survey; (b) by unlicensed surveyor; (c) for a fee or reward; and in the absence of proof of any one of these ingredients the claim for recovery of the penalty must fail. I am of the opinion that the claim should be dismissed.

In Niger Dams Authority v Chief Victor Ladipo Lajide ${ }^{17}$. The Supreme Court said though by way of obiter dictum that "where a case is stated for the opinion of the High Court from an arbitrator, the court ought to confine itself to the legal questions referred thereby. In the instant case, the question which was referred to the court was not whether the certificate issued by the consultant engineers was valid or ultra vires but whether the forfeiture was in accordance with the terms of the contract. The court held that 'barring any imputation of mala fides, ultra vires or fraud, the consultant engineers' certificate was unimpeachable, and for this reason, the appellants were entitled to exercise their reserved right of forfeiture and re-entry into the works and retain the respondents' plants and materials thereon.'

A case could also be stated by the High Court to an Arbitrator or a Referee provided a law enables the same. In Duke \& Ors v Archibong \& Anor" It was held that "Sections 59 and 60 of the Eastern Region High Court Law make provision for sending, respectively, questions for report by a referee or whole causes or matters or questions arising therein for trial by an arbitrator. Orders XLIV and XLV respectively regulate the procedure for such references. It is essential for any court referring any question or cause to a referee or arbitrator to state under which of the two sections it is acting when doing so."

When stating a case the court stating the case should state the specific question(s) the higher court is required to give answer or answers to. In John Agwunobi v Eze Ezeonyido \& 11 Ors ${ }^{19}$,

\footnotetext{
${ }^{17}$ (1973) East-Central State of Nigeria Law Reports 361; (1973) 8 NSCC 342. The respondent, a firm of building contractors, agreed to build eleven resettlement villages for the appellants within a stipulated time. The appellants reserved a right of forfeiture and re-entry upon their consultant engineers certifying that the work was not progressing as rapidly as desired and on re-entry, they were at liberty to put in more hands and deduct the cost of completion from the contract price payable to the respondent. The respondent defaulted and the appellants on receiving their consultant engineers' certificate exercised their right of forfeiture; re-entered the site and retained the respondent's plants and materials thereon. Subsequent upon the said re-entry, an arbitrator, a chartered accountant, was appointed who stated a case for the High Court to determine whether the forfeiture was in accordance with the terms of the contract and also whether the retention of the respondent's plants and materials was lawful. The High Court ruled on this issue by holding that the consultant engineers' certificate was not absolute and as such was open to review by the arbitrator. Furthermore, the forfeiture was ultra vires. On appeal, counsel for the appellants submitted that the trial judge erred in law by holding that the forfeiture was ultra vires or that the consultant engineers' certificate was invalid or inconclusive against the respondent and further, that the trial judge exceeded his authority by questioning the validity or otherwise of the consultant engineers' certificate. Counsel for the respondent contended that the certificate was a nullity and that the forfeiture clause being in the nature of a penalty clause, ought to be strictly construed.

${ }^{18}$ [1959] (Vol.1) NSCC 97.

19 (1973) E.C.S.N.L.R per Oputa J. The complainant by way of private prosecution instituted an action against the defendant and eleven others. At the preliminary inquiry the learned Magistrate acting under section 31 of the
} 
the court held that: 'A Magistrate stating a case should comply with section 33 of the Magistrates' Courts Law by stating the specific question or questions of law to which the High Court would be required to give some answer or answers.'

\section{REFERENCE OF CONSTITUTIONAL QUESTIONS}

Where any question relating to the interpretation or application of this Constitution arises in any proceedings in any court of law in any part of Nigeria (other than in the Supreme Court, the Court of Appeal, the Federal High Court or the National Industrial Court, a High Court) and the court is of the opinion that the question involves a substantial question of law, the court may, and shall if any of the parties to the proceedings so requests, refer the question to the Federal High Court or the National Industrial Court, a High Court having jurisdiction in that part of Nigeria ${ }^{20}$ and the Federal High Court or the National Industrial Court or a High Court shall if it is of the opinion that the question involves a substantial question of law, refer the question to the Court of Appeal ${ }^{21}$ or if it is of the opinion that the question does not involve a substantial question of law, remit the question to the court that made the reference to be disposed of in accordance with such directions as the Federal High Court or National Industrial Court or the High Court may think fit to give. ${ }^{22}$ It should be noted that under section 295 of the Constitution, there is no provision for reference to the Shariah or Customary Court of Appeal of a state or other courts that may be on the same pedestal as the High Court. Should an issue arise regarding the application of this section of the Constitution to these courts that are on the same ranking as a High Court or Federal High Court, would the Latin maxim Expressio Unis Est Exclusio Alterius ${ }^{23}$ apply? Or would the provisions of section 6(5) (a)-(k) of the Constitution which lists out the Superior courts of record to include the aforementioned courts be resorted to? It should also be noted that under these provisions the High Courts and other courts therein mentioned cannot answer the questions referred from an inferior court but shall to refer it/them to the Court of Appeal where it considers the questions to be substantial in nature or give directions as to how the referred questions should be disposed of where it considers that the questions do not involve substantial questions of law.

Where any question as to the interpretation or application of this Constitution arises in any proceedings in the Federal High Court or a High Court, and the court is of the opinion that the question involves a substantial question of law, the court may, and shall if any party to the proceedings so requests, refer the question to the Court of Appeal; and where any question is referred in pursuance of this subsection, the court shall give its decision upon the question and the court in which the question arose shall dispose of the case in accordance with that decision. ${ }^{24}$ Note that the Court of Appeal here is required to give a decision and not refer the questions to the Supreme Court unlike the case of reference from inferior courts of record to

\footnotetext{
Magistrates' Courts Law “stated a special case on a point of law for the opinion of the High Court". The issue was whether a Magistrate could when holding a preliminary inquiry which by section 2 of the Criminal Procedure Law means "an investigation of a criminal charge... with a view to the committal of an accused person for trial before the High Court" state a case for the opinion of the High Court.

${ }^{20}$ See Section 295(1) CFRN 1999.

${ }^{21}$ See Section 295(1) (a) CFRN 1999.

${ }^{22}$ See Section 295(1) (b) CFRN 1999.

23 'The express mention of one thing is the exclusion of another.'

${ }^{24}$ See Section 295(2) CFRN, 1999.
} 
the High Court or Federal High Court. However, giving a decision has been held not to be the same as answering the question. ${ }^{25}$

Where any question as to the interpretation or application of this Constitution arises in any proceedings in the Court of Appeal and the court is of the opinion that the question involves a substantial question of law, the court may, and shall if any party to the proceedings so requests, refer the question to the Supreme Court which shall give its decision upon the question and give such directions to the Court of Appeal as it deems appropriate. ${ }^{26}$

A comparison of section 295 of the 1999 Constitution with section 108(2) of the 1960 Constitution of the Federation which provides that where there is a question of interpretation of the Constitution or the Constitution of a region and the court is of the opinion that a substantial question of law is involved, the Court may, if any of the parties to the proceedings so requests, refer the matter to the Federal Supreme Court shows that the two provisions are similar with the difference being that the former includes the application of the Constitution while the latter does not. See the dictum of Bello CJN in Atake v Afejuku ${ }^{27}$

In Bamaiyi $v A G F^{28}$ the Supreme Court in pronouncing on who can invoke section 295 of the 1999 Constitution held "The court is vested with the discretion to invoke the provision suo motu and also if the parties to proceedings so request. Thus the Court may suo motu and must make reference on the parties' request."

Agreement between the parties that a constitutional question should be referred to a higher court does not relieve the lower court of its duty independently to decide whether the question genuinely arises in the proceedings and involves a substantial point of law; and whether its determination is necessary to the determination of the proceedings. ${ }^{29}$

\footnotetext{
${ }^{25}$ See Bamaiyi v AGF 7 NSCQR 599 at 609. The appellant who was the Chief of staff of the Nigerian Army during the regime of late General Sani Abacha was invited by the $2^{\text {nd }}$ respondent for questioning over his alleged role in facilitating the provision of arms used in the attempted murder of Mr. Alex Ibru. The appellant was detained in a house at Forte IBB Barracks, Abuja. The appellant sought leave to enforce his fundamental right challenging his detention and applied to the Federal High Court that his arrest is without justification, illegal, unlawful and consequentially, a violation of his fundamental right as secured by sections 35 and 41 of the 1999 Constitution. He also asked for some other prayers. The trial court granted most of the prayers sought but the appellant was not released. Instead, he was flown to Lagos where he was arraigned before a Chief Magistrate on a two-count charge of conspiracy and murder. He was remanded in Kirikiri Security Prison, Lagos. The appellant's counsel filed several applications seeking a committal order for the $1^{\text {st }}$ respondent for contempt of the court's order, release of the appellant from Kirikiri Prison and for stay of proceedings in suit No. MK/A/912 pending the hearing of the appellant's application for the enforcement of his rights. When the suit came up for hearing before the trial court, the appellant's counsel moved the court to refer the following constitutional question for the interpretation of the Court of Appeal: "Whether by the provision of section 174 of the Constitution or any provisions the Federal Attorney-General has the power to constitute the Special Investigation Panel that investigated the applicant and the report which forms the basis of the charge against him before the Magistrates Court?" The Court of Appeal refused to answer the question on the ground that it did not arise from the proceedings before the trial Court. The case was sent back to the High Court for continuation of hearing of the applications. Dissatisfied, the appellant appealed to the Supreme Court.

${ }^{26}$ See Section 295(3) CFRN, 1999.

27 [1994] 12 SCNJ 1 at 12, (1994) 4 NWLR (Pt. 368) 379.

${ }^{28}$ Supra.
}

${ }^{29}$ See Gamioba v Esezi. [1961] NSCC (Vol. 2) 238. The Plaintiffs brought an action against the defendant in the High Court claiming a declaration that a certain trust instrument was either invalid or void and an injunction 
In Atake vAfejuku $u^{30}$, the Supreme Court held inter alia, that the provision of Section 259(3) of the 1979 Constitution (which is on all fours with Section 295(2) of the 1999 Constitution except that Section 259(3) related to reference from the Court of Appeal to the Supreme Court), is clear and unambiguous and that a question as to the interpretation or application of the Constitution is the foundation for making reference by the Court of Appeal to the Supreme Court under the subsection. It was also held that any question of law, however substantial it may be, which does not involve the interpretation or application of any of the provisions of the Constitution is outside the ambit of the subsection and is therefore not referable. The court further held that a question of the interpretation or application of Section 340 of the Criminal Procedure Law of Lagos State, is incompetent for reference under Section 259(3) of the 1979 Constitution. The Supreme Court in the same manner held in Abaji Area Council \& Ors v. Joseph Ona \& Ors. ${ }^{31}$ that the reference to the Court of Appeal was absolutely uncalled for.

In Gamioba \& Ors v Esezi II \& Ors ${ }^{32}$ and FRN $v$ Ifegwu ${ }^{33}$ It was held that the power to refer a question of law as to the interpretation and application of the Constitution to a higher court does not include the power to transfer the case for hearing and determination to the higher court.

The question must involve a substantial question of law. ${ }^{34}$ In Bamaiyi $v A G F^{35}$ the Supreme Court was of the opinion that 'it is not just every question requiring constitutional interpretation that should be referred to the Court of Appeal' and held that section 295 of the 1999 Constitution can only correctly be relied upon in proceedings in any Court of law in Nigeria,

\footnotetext{
restraining the defendant from implementing the instrument. The statement of claim alleged, inter-alia, that the instrument was made in the exercise or purported exercise of powers ultra vires the Nigeria (Constitution) Order in Council 1960 or inconsistent with it, and that in the alternative, the instrument was invalid as an improperly constituted trust or was void for uncertainty. From the records, no pleadings had been ordered when both counsel joined in making an application to the High Court that the suit raised a question as to the interpretation of the Nigeria (Constitution) Order in Council involving a substantial question of law and requesting the Court to refer the question to the Supreme Court. The question was as to whether the power conferred on the Minister under section 4 of the Western Region Law to appoint trustees in respect of Communal Right was inconsistent with the provision of the Nigeria Constitution. The judge of the High Court therefore ordered that pursuant to section 108(1) of the Constitution, the cause be transferred from the High Court of Justice, Warri Judicial Division, to the Federal Supreme Court, Lagos, for hearing and determination.

30 Supra.

${ }^{31}$ [2004] 11-12 S.C 1

${ }^{32}$ Supra.
}

33 (2003) 9-10 S.C. 128. In the Failed Bank Tribunal, Lagos Zone II, the accused/respondent was arraigned on a two-count charge. After the conclusion of evidence and addresses of counsel on both sides, the Respondent was duly convicted of two counts and sentenced. The Respondent aggrieved by the decision of the Tribunal exercised his right of appeal in accordance with the provisions of the Failed Banks Decree No.18 of 1994 to the Special Appeal Tribunal. The Special Appeal Tribunal duly considered the appeal. It confirmed the convictions but allowed the appeal on sentences only. After waiting for a period of two years, the Respondent approached the Federal High Court, Lagos by an Originating Summons dated $31^{\text {st }}$ May, 1999, praying for a declaration that the Failed Banks Tribunal as well as the Special Appeal Tribunal lacked the jurisdiction to have tried, convicted and sentenced him on the two counts of charge preferred against him in view of the provisions of section 33(8) and Section 33(12) of the 1979 Constitution applicable at all material times relevant to the trial. Meanwhile, the Respondent prayed the Federal High Court to transfer the suit to the Court of Appeal held in Lagos by way of case stated pursuant to Section 295(2) of the 1999 Constitution (Section 259(2) of the 1979 Constitution).

${ }^{34}$ See Gamioba \& Ors $v$ Esezi II \& Ors supra.

${ }^{35}$ Supra per Uthman Mohammed JSC at 610. 
where: (i) Any question of interpretation or application of the Constitution, had arisen, and (ii) The court is of the opinion that the question involves a substantial question of law. ${ }^{36}$

In Olawoyin v C.O.P $P^{37}$, it was held that for a question to be a substantial question of law, it must be such that there may be some doubt or difference of opinion as to what the law is. In Gamioba $v E^{2}$ zi $^{38}$, the court held that "While not a complete definition, a "substantial question of law" must be one on which arguments in favour of more than one interpretation might reasonably be adduced.' In Labour Party v I.N.E.C , $^{39}$, the Court of Appeal per Augie JCA (as he then was) held that:

Section 295(2) of the 1999 Constitution clearly stipulates that where any question has to do with the interpretation and application of the Constitution, and the Federal High Court or High Court is of the opinion that the question involves a substantial question of law, it may refer the question to this court. All the authorities agree that the constitutional question sought to be resolved must be so crucial that, without its resolution as a preliminary point, it would not be possible to resolve the main suit. The question must also be one which clearly favours more than one interpretation: Dasuki v. Miazu (2002) 16 NWLR (pt.793) where the court held as follows: "The Supreme Court in its earlier decisions refrained from giving an exhaustive meaning of what is a substantial question of law. But it is safe and necessary to say that where a question which arises in a High Court is one of general public importance or interest and it directly and substantially affect the right of the parties and that it is still an open question in that it has not been pronounced upon in a binding decision by the Supreme Court and either that it is not free from difficulty or there is a difference of opinion or confusion as to what the law is; then it is a substantial question of law".

\footnotetext{
${ }^{36}$ Per A.G.Karibi-Whyte JSC (as he then was) at 615.

37 [1961] NSCC (Vol. 2) 261 The Appellants appealed to the High Court from convictions of certain offences, contending that the refusal by the trial court to give them an opportunity to further examine prosecution witnesses amounted, in the circumstances, to a violation of their constitutional right to a fair trial. The High Court, at their request, referred two questions to the Federal Supreme Court under section 108 of the Constitution of the Federation. The questions set out the circumstances under which the Appellants contended that their right to a fair trial had been violated, and prayed the Supreme Court to decide whether the Constitutional guarantees of a fair trial, provided for by sections 21(2), 21(4) and 21(5) of the Constitution of the Federation had been denied to them, in the proceedings before the trial court, by that court's refusal to permit the requested further examination of prosecution witnesses. The Appellants sought to reframe the questions in the Supreme Court.

${ }^{38}$ Supra.

${ }^{39}$ [2008] All FWLR (pt.448) 312 at 336-337. The plaintiff/applicant herein submitted questions to the Federal High Court sitting at Katsina. The court granted the application referring the constitutional questions to the Court of Appeal for determination. The questions were brought pursuant to section 295(2) of the Constitution of the Federal Republic of Nigeria, 1999 requiring the Court of Appeal to answer the constitutional questions referred by the Federal High Court.
} 
In Bamaiyi $v A G F^{40}$, it was held per Karibi-Whtye (JSC as he then was) on this issue that: 'Thus, for a question of law to be substantial, it must be such that there may be some doubt or difference of opinion as to what the law is. When no such doubt exists, or the law is well established by a final Appellate Court, or by an overwhelming consensus of judicial decisions, the mere application of it to a particular set of facts does not constitute a substantial question of law, however important the issue may be for the decision of the particular case.' And on the attitude of Appellate Courts to academic questions the Supreme Court in the same case held that: 'Where a question before the court is entirely academic, speculative or hypothetical, the Appellate Court in accordance with well-established principles must decline to decide such a point. ${ }^{41}$

However and as earlier stated, the Supreme Court ${ }^{42}$ has held that the higher court does not have to answer the question. All it needs to do is to make a decision which is not the same as answering the question. Precisely, the Court per Karibi-Whyte JSC (as he then was) posited thus: "I cannot imagine any language more explicit. The sub-section says "the court shall give its decision upon the question" so referred to the court. It is to be observed that this is not the same as saying "the court shall answer the question". See however the decision in Labour Party $v$ I.N.E.C $C^{43}$, where it was held that the Higher court is duty-bound to answer the questions referred by the lower court.

The questions must genuinely arise in the proceedings at the lower court making the reference. In Bamaiyi v $A G F^{44}$ it was held that: 'It is an essential condition for the exercise of the power in the constitutional provision that the question must genuinely arise in the proceedings. For the question to arise genuinely, it must be one, which must necessarily be decided in the cause or matter and not a matter, which may prove unnecessary to be decided.'

${ }^{40}$ Supra at 616

${ }^{41}$ Ibid per Iguh JSC (as he then was) at 620.

${ }^{42}$ Bamaiyi v AGF, supra at 609 per Karibi-Whtye JSC (as he then was).

43 Supra.

${ }^{44}$ Supra per A.G. Karibi-Whyte JSC at 615. See also Salami \& 3 Ors v Mil. Gov. of Ogun State \& 2 Ors [1985] HCNLR 817. The Ogun State government promulgated the Commercial Vehicles, Tippers and Trailers (Special Permit) Edict No. 4 of 1984. Section 3 of the Edict prescribes special Permit/Licence obtainable upon payment of specified fees in respect of heavy commercial vehicles, trailers and tippers when carrying building materials on Ogun State roads. The Plaintiffs then brought the present suit in which they sought a declaration that section 3 of the Edict is inconsistent with Section 5(1) of the Road Traffic Act Cap. 184 Laws of the Federation of Nigeria 1958 and the provisions of the Constitution and accordingly is void to the extent of inconsistency. They also sought an injunction against the enforcement of the said section 3 of the Edict. The Plaintiffs did not, however, specify the section of the Constitution on which they are relying. Section 5(1) of the Road Traffic Act provides: "The owner of a motor vehicle or trailer may register the same and obtain a license which shall be valid throughout Nigeria in respect thereof in accordance with the regulations made under this (Ordinance) Act PROVIDED that no licence valid for a period of more than 14 days shall be issued by any Licensing Authority unless such Licencing Authority is situate either: within the region in which the owner ordinarily resides or within the region which the motor vehicle or trailer is normally operated in any case where such region is other than the region in which the owner ordinarily resides." Almost all the states of the Federation have a provision similar to that of section 5 of the Road Traffic Act which is a Federal Legislation in their Road Traffic Law. At the hearing counsel to the Plaintiffs applied for reference to the Court of Appeal for the determination of some legal points he raised on the interpretation of the statutory provision. 
In Queen $v$ Amalgamated Press ${ }^{45}$ it was held that the questions must be specifically put by the lower court and in Gamioba $v$ Esezi ${ }^{46}$ it was held that the question must be one capable of being formulated with precision.

In Olawoyin v C.O.P $P^{47}$, it was held that the higher court is limited in its answers to the questions referred to it and will not allow questions to be reframed so as to turn them to different or additional questions.

Once a decision has been given by the higher court on a substantial question of law, the same question cannot be referred to by way of reference in that same case. The way to obtain a review of that decision is by way of an appeal. See Adesanya $v$ President ${ }^{48}$

When a reference is being made to a higher court, the lower court must not give a decision on the substantial question being referred. Such courts can only state facts or make findings of facts. See Adesanya $v$ President ${ }^{49}$.

Where finding of facts is necessary before the higher court can properly interpret the Constitutional questions referred to it then it is the duty of the trial court to first of all do the same. Order 5 Rule 3(b) of the Court of Appeal Rules, 2016 buttresses this point. It provides that 'A case stated shall state such of the findings of fact as are necessary to explain the question on which the decision of the Court is sought but except where in a criminal matter, the question is whether the evidence to support any decision, or whether the evidence for the prosecution

\footnotetext{
${ }^{45}$ [1961] NSCC (Vol.2) 101. The defendants were arraigned before the High Court of Lagos on an information charging them with the offences of publishing a seditious publication contrary to section 51(1)(c) of the Criminal Code, and (2) publishing false news likely to cause fear and alarm contrary to section 59(1) of the Criminal Code. At the end of the trial counsel for the defence submitted, inter alia, that in view of the provisions guaranteeing the Fundamental Human Right of Freedom of Expression contained in the Constitution of the Federation (section 24) the two sections of the Criminal Code under which the defendants were charged had become null and void as they were repugnant to the Constitutional guarantees. He requested the trial judge to refer the point to the Federal Supreme Court under the provisions of section 108 of the Constitution. The trial Judge made no findings but adjourned the case sine die for further consideration and judgment, and stated that he referred the point raised to the Supreme Court. However, no specific questions were formulated for the Supreme Court's consideration.
}

46 Supra.

47 Supra

${ }^{48}$ [1981] (Vol.1) NSCC 97. The plaintiff/appellant was a senator of the National Assembly. The second respondent was appointed by the first respondent, as chairman of the Federal Electoral Commission, and the appointment was ratified by the Senate, after a debate in which the appellant took part. The plaintiff challenged this appointment, claiming that the $2^{\text {nd }}$ respondent was a public officer (Chief Judge of Bendel State) both at the time of the appointment and at the time of confirmation, and as such, he was disqualified from being appointed a member of the Federal Electoral Commission, and such appointment was null and void. The action was in essence one of "declarations of right". The High Court of Lagos held in favour of the plaintiff. The respondents appealed to the Federal Court of Appeal, contending that the plaintiff had no locus standi to institute such an action. The counsel for the appellant maintained that he had locus standi and asked that the matter be referred to the Supreme Court under Section 259(3) of the Constitution for the correct interpretation of sections 6(6)(b), 33(1), 48, 141, \& 236(1) of the Constitution, 1979. The Court of Appeal first determined the question itself before referring it to the Supreme Court for another decision.

${ }^{49}$ Supra. 
disclosed a case for the defendant to answer, it shall not contain a statement of the evidence." In Idris $v A u d u^{50}$, Omoleye JCA opined thus:

"It is crystally (sic) apparent from the record that the trial court has virtually wholesale transmitted the suit to this court for hearing and determination. As earlier stated, since there is a serious contest between both parties which is very obvious, the making of findings of fact has become a sine qua non precedent to a proper and meaningful reference to this court. Since there are no findings of fact, this court is handicapped and cannot now approximately proceed with the determination of the questions sought to be referred by the respondent. It is the trial court that possesses the requisite jurisdiction to make findings of fact in the matter between the parties pursuant to the provisions of section 6(2), (5) (e) \& (6) of the 1999 Constitution. The sub-sections of that section provide that judicial powers of a state are vested in the High Court as touching all matters between persons, or between governments or authorities and to all actions and proceedings relating thereto, for the determination of any question as to the civil rights and obligations of persons, governments or authorities. The trial court should and cannot be allowed to shy away from this constitutional obligation and duty.

It is my humble view that the provisions of section 295(2) of the 1999 Constitution has not been strictly complied with. There is no doubt that the instant application for reference is unripe and abortive. Consequently, I hold that it is improper, invalid and totally lacking in competence.

In Gamioba $v$ Esezi $i^{51}$ It was held that 'A Reference to a higher court is premature if there remains undecided by the lower court any issue which could finally determine the proceedings without recourse to the constitutional question referred.'

In D.P.P v Obi (No.2) $)^{52}$, it was held that a decision in a constitutional reference is not a final decision as regards the proceedings from which reference was made but final on the interpretation of the constitutional provisions referred.

Where a Plaintiff claims a declaration that a law is invalid, the lower court should be satisfied that his legal rights have been, or are in imminent danger of being invaded in consequence of

50 [2008] All FWLR (pt.422) 1122 at 1171, paras B-F

51 Supra.

52 [1961] NSCC (Vol. 2) 213. During the trial of the Appellant in the High Court on a criminal charge, the High Court referred a question as to the interpretation of the Constitution to the Federal Supreme Court under section 108(2) of the Constitution of the Federation. The answer given by the Federal Supreme Court to the question under reference was not favourable to the Applicant and the Applicant was subsequently convicted in the High Court. The Applicant, before his appeal was determined, applied for leave to appeal to the Privy Council against the decision of the Federal Supreme Court on the reference under section 108(3) of the Constitution of the Federation. It was argued for the Applicant that the decision on the reference was a "final judgment" and that section 114(1)(c) of the Constitution of the Federation conferred on him a right of appeal "as of right" against the decision on the reference. 
the law, before referring the question to the higher court. The Courts will not pronounce on the constitutionality of a statute, unless it is necessary to preserve the rights of the parties. ${ }^{53}$

Reference and Case Stated are both different from judicial review which is more like transferring the case, evidence and all to a higher court for its review. Reference and Case Stated are purely about questions of law or constitutional questions being referred to a higher court. This distinction is in our opinion illustrated by the case of Jos N.A. Police v Allah Na Gani $^{54}$, the High Court per Reed, S.P.J in discharging and acquitting the accused said "we are indebted to Inspector of Native Courts Mustapha Mohammed Yola for reporting this case and we commend the able manner in which he reported it. We are also indebted to State Counsel for the assistance he has given us in this review. We set aside the conviction of Allah Na Gani in the Chief Alkali's Court and the sentence of three years imprisonment. We substitute an order of acquittal and discharge him.

In African Newspapers Ltd \& Ors v FRN ${ }^{55}$, it was held that the Court of Appeal may suo muto make a reference where none of the parties request and shall if they request notwithstanding that the Court of Appeal had taken a different decision in another case where neither the Court of Appeal nor the parties requested a reference provided the Supreme Court has not pronounced on the issue.

All the conditions precedent for a reference to be made must co-exist and must be in place before any reference known to law can properly be made. ${ }^{56}$

\footnotetext{
${ }^{53}$ See Gamioba v Esezi supra.

${ }^{54}$ [1967] NNLR 107 at 110. The defendant was convicted in the court of the Chief Alkali of Jos of the rape of a seven year old girl contrary to section 283 of the Penal Code. The conviction was based upon the uncorroborated evidence of one witness contrary to section 178(5) Evidence Law. The case was referred to the High Court under section 52 of the Native Courts Law. In order to elucidate the point being made here, the provisions of the law pursuant to which the case was referred to the High Court for review are reproduced here to wit: Section 50(1) Area Court Law - "An inspector, if in his opinion there has been a miscarriage of justice in any case before an area court to which he has access under the provisions of section 47, may of his own motion or in his absolute discretion on the application of any person concerned, report that case to the court to which an appeal in such case would lie. Such report should be in writing and shall record the particulars of the judgment or the order or the case, and the reason of its being reported and shall be accompanied by a copy of the record of the case. Section 50(5) An inspector who has reported any case to a court under the provisions of this section shall have power to make an interim order suspending the operation of any sentence or order made by the lower court in such a case, or admitting to bail any person sentenced to imprisonment therein by the lower court. Section 50(6) A person aggrieved by a decision of the High Court in a review under this section may appeal therefrom as if it were a decision in an appeal to the High Court from some other court. Section 52 - No inspector shall exercise the powers conferred upon him by this Part in any case where a party aggrieved by the decision of the area court has appealed therefrom or otherwise instituted any appeal proceedings in respect thereof.

${ }^{55}$ [1985] 1 NSCC (Vol. 16) 405. The appellants were charged before the Federal High Court with the offences of seditious publications and publication of false news. Counsel to the appellants raised a preliminary objection that the criminal jurisdiction of the Federal High Court is limited to offences connected with or pertaining to the revenue of the Federation and contended that the court was not competent to try the appellants on the offences with which they were charged. The Federal High Court, after considering the arguments of counsel, held that it had jurisdiction to entertain the case, and relied on the decision of the Court of Appeal in the Federal Republic v Eze (1982) 3 N.C.L.R 259.
}

${ }^{56}$ See Idris v Audu supra. 
For a constitutional question to arise in the course of proceedings, it must not have formed part of the questions for determination in the original suit and certainly not claims raised by either party in the substantive matters before the trial court ${ }^{57}$.

The Higher court is not directly concerned with the reliefs sought before the lower court, nor will it grant or refuse those reliefs. It is not even within its purview to consider same. The reliefs shall be considered, granted, or refused by the court below. Thus apart from the constitutional questions thrust upon the higher court for answers, the court cannot go into the merit or otherwise of the substantive matter before the court below. ${ }^{58}$

There is a clear distinction between an application for reference and an appeal which is defined as an invitation to a higher court to review the decision of a lower court whether on the proper consideration of the facts placed before it, and the applicable law, that court arrived at a correct decision $^{59}$. In a similar vein, the Supreme Court in F.R.N $v$ Ifegwu $^{60}$ opined that matters of reference are not matters of appeal to be considered under the appellate jurisdiction of the Court of Appeal, but are matters of special jurisdiction.

The constitutional questions for reference must be connected to the case before the lower court. In Bamaiyi $v A G F^{61}$, the Supreme Court posited that:

In the instant case the proceedings before the Federal High Court which was seeking declaratory reliefs relating to the human rights of the Appellant did not concern a question of the interpretation of section 174 of the 1999 Constitution, which relates to the powers of the Attorney-General of the Federation, which was not an issue before the trial Judge in the Federal High Court.... The Court of Appeal was therefore right in declining to answer the question referred to it. The court correctly referred the question back to the referring trial Federal High Court for continuation of the proceeding before it. In the circumstances where the reliefs relating to the constitutional questions referred was founded on issues no longer part of the declaratory reliefs and the proceeding before the learned trial Judge, it will be completely inappropriate to formulate a question unsupported by any material before him, and not constituting any of the issues in dispute before him.

The Supreme Court in Bamaiyi v $A G F^{62}$ also pronounced when section 295(2) 1999 Constitution is mandatory to the effect that the mandatory nature of the constitutional provision applies only where parties resort to it and request a reference. It does not apply when the court applies the provision suo motu.

\footnotetext{
${ }^{57}$ See Idris $v$ Audu supra.

${ }^{58}$ See Labour Party v I.N.E.C supra.

${ }^{59}$ Per Augie JCA (as he then was) in Labour Party v I.N.E.C. supra.

${ }^{60}$ Supra.

${ }^{61}$ Supra per Karibi-Whyte at 619-620.

${ }^{62}$ Per Karibi-Whyte JSC (as he then was) at 618.
} 
On the quorum of the Supreme Court when entertaining constitutional questions referred to it, the Supreme Court per Onnoghen JSC (as he then was) in Associated Discount House Ltd v Amalgamated Trustees (No.2) ${ }^{63}$ opined that:

In other words, the decision to empanel either 5 or 7 Justices to hear a particular case depends on the nature of the case, its complexity, significance, public or legal interest or novelty, as submitted by learned counsel for the respondent. In that case, it is not always that where an application of any provision of the Constitution is required that a seven member Justices must be empanelled to hear the matter. I hold the view that in such a situation, a panel of five Justices can and do legally constitute the court for the purpose of determining the matter.

In reference to constitutional questions, it is the questions referred that are argued in the brief and not issues for determination since there are no grounds of appeal from which such issues could have been distilled. In that connection, the Supreme Court in F.R.N v Ifegwu ${ }^{64}$ opined that:

It is obvious that under these provisions, it is the court that refers the question or questions to the Court of Appeal, which I believe must be under its hand or authority only as shown on page 3 of the record. However, in the Court of Appeal the parties filed briefs of argument as required by the Rules of the court. In the Plaintiff/Respondent's brief, (pages 154-170 of the record), Prof. Adesanya, SAN, learned counsel for the Plaintiff/Respondent submitted four(4) issues for determination (pages 158-159) by the Court of Appeal. Thus abandoning the two (2) reference questions completely. Where did these issues come from? There were no Grounds of Appeal. So they could not have been distilled from any Ground(s) of Appeal. Counsel is also without power to substitute his own "issues" for the reference questions of the Federal High Court. The two reference questions ought to have been struck out by the court. I hereby strike them out.

\footnotetext{
${ }^{63}$ [2007] 7 S.C 168 at 211. The respondent/applicant was respondent before the Supreme Court in an interlocutory appeal on issue of jurisdiction between the same parties. Briefs were exchanged and the appeal was heard before a panel of five (5) Justices which panel set aside the judgment of the lower court and held instead that the Lagos State High Court was vested with jurisdiction to hear the claim. The judgment of the Supreme Court in the appeal has been reported in (2006) 5 S.C. (Pt. 1) 32.

${ }^{64}$ Supra.
} 


\section{CONCLUSION}

From the discourse above, it is our conclusion that both terms involve stating a question of law or a question that arises from the interpretation or application of the Constitution to a higher court in the hierarchy of courts. While their differences include the fact that a constitutional reference is provided for by the Constitution and not by a statute unlike when a case is being stated. Also, constitutional reference applies only to constitutional matters involving substantial question(s) of law while a case stated applies to any point of law not necessarily constitutional.

Also, provisions of statutes like section 106(1) of the Lagos State Land Registration Law, 2014 show that a case stated could be made by persons exercising purely administrative functions or quasi-judicial functions. It is not limited to persons exercising judicial functions unlike reference under section 295 of the 1999 Constitution. 